\title{
Empirical Relationship of Company's Intangible Resources and Corporate Financial Performance- A Panel Data Approach
}

\author{
Vikram Jeet $^{1, *}$, Parvesh Kumar Aspal ${ }^{2}$ \\ ${ }^{1}$ Department of Business Administration, University of Jeddah, College of Business, Jeddah, Saudi Arabia \\ ${ }^{2}$ Department of Finance and Accounts, IKG Punjab Technical University, Jalandhar, Punjab, India
}

Received September 15, 2021; Revised October 24, 2021; Accepted November 21, 2021

\section{Cite This Paper in the following Citation Styles}

(a): [1] Vikram Jeet, Parvesh Kumar Aspal, "Empirical Relationship of Company's Intangible Resources and Corporate Financial Performance- A Panel Data Approach," Universal Journal of Accounting and Finance, Vol. 9, No. 6, pp. 1533-1543, 2021. DOI: 10.13189/ujaf.2021.090630.

(b): Vikram Jeet, Parvesh Kumar Aspal (2021). Empirical Relationship of Company's Intangible Resources and Corporate Financial Performance- A Panel Data Approach. Universal Journal of Accounting and Finance, 9(6), 1533-1543. DOI: 10.13189/ujaf.2021.090630.

Copyright $(2021$ by authors, all rights reserved. Authors agree that this article remains permanently open access under the terms of the Creative Commons Attribution License 4.0 International License

\begin{abstract}
The present analysis proposed a model to explain the impact of corporate intangible resources, such as research \& development (R\&D), human capital, and corporate reputation on corporate financial performance. The corporate financial performance was measured with two determinants, return on assets (ROA) \& return on equity (ROE). The data had been collected from 81 different manufacturing and consumer goods companies for three years from 2014 to 2016. To investigate the association considering the intangible resources and control variables, the panel data regression is applied. For the descriptive analysis, the mean, dispersion, and correlation among all the variables are examined and the redundant fixed effect test is applied to choose an appropriate model between panel data regression and pooled OLS regression. The study results highlighted that the intangible resources human capital and research \& development have significantly and positively impacted the financial performance indicators ROE and ROA. However, the intangible resource corporate reputation significantly, but negatively affects the corporate financial performance ROE and ROA. Likewise, the control variable leverage has a significant impact, but the size has an insignificant effect on corporate financial performance. The study highlights the importance of a firm's intangible recourse in the organizational performance and gives a wider scope to investigate the influence of other intangible resources on organizational financial performance.
\end{abstract}

Keywords Research \& Development (R\&D), Human Capital, Corporate Reputation, Return on Assets, Return on Equity

\section{Introduction}

The intricacy and intensity of the modern economy are consistently challenging. The corporate managers contend effectively to emerge as world-class companies by providing the premier quality services and products in a timely responsible approach along with creating collective learning capabilities [1]. Generally, the traditional strategic managerial approach concentrated exclusively on maximizing the profits in a legitimate manner without recognizing the worth of corporate reputation that can facilitate a sustainable competitive advantage to the company [2]. Thus, the global strategic managers with collective competence are now concentrating and envisioning the formulation of strategic planning that enhances sustainable corporate competitive advantage [3]. Successful corporate managers, while executing their substance skills and leadership styles, exercise the leverage of corporate competitive advantage in strategic planning.

Conventionally the physical resources such as land \& 
material and capital were acknowledged as valuable determinants of the organizational economic performance [4]. However, globalization has transitioned the blueprints of the production structure, which is now primarily driven by corporate reputation, talented human capital, and innovation [5]. In the competitive business environment that is widely viewed as the knowledge economy, the intangible resources are eventually recognized as the competitive edge of the corporations to enhance their earning avenues [6]. The organizations that have managed their intangible resources in a better manner have attained a stronger competitive advantage over their rivals and play a crucial role in sustaining the long-term economic performance [7]. The intangible resources are also considered as significant determinants of corporate success, as these are scarce and difficult to imitate for competitors [8]. Similarly, intangible assets like knowledge, human capital, innovativeness, corporate reputation, and risk-seeking capability contribute more than tangible resources to creating corporate value [9].

Corporate tangible resources are the productive assets through which the operations are brought about. On the same pattern, technical know-how, human capital, and other intangible resources characterized by the company popularize its products and services effectively and efficiently. Moreover, intangible resources contribute more as compared to tangible resources to creating corporate value [10]. The combination of intangible resources with physical assets within the organization is a strategic arrangement that induces a new set of operations and business models for a new source of corporate revenues [11]. Under the knowledge-based aspect, the corporation enjoys the trade secrets, accumulated proprietary skills, organizational culture, and intellectual property that are valuable, rare and inimitable, but can be best transferred within hierarchy of the corporation [12].

In the present study, the first part of the study bestows to the literature by expressing the role of intangible resources in the sustainability of organizations in the competitive business environment. In the second section, a review of literature presents the evidence of the association between corporate profitability and corporate intangible resources and its impact on the financial performance of the corporation. The third section reflects the study purpose and rationale; likewise, section four represents the theoretical framework for hypotheses development, and empirical investigation. However, the fifth section represents the investigation of empirical findings and their discussions. And the final section represents the conclusion and managerial implications of the study.

\section{Review of Literature and Hypothesis Formation}

Competitive advantages of an organization are a combination of human capital, physical capital, and structural capital resource base of the firm that deploy intangible and tangible assets to improve performance [13]. Mainly, the intangible resources are internally developed assets of the firm, which are rare, inimitable, and valuable. The empirical and descriptive relationship of intangible resources such as "Human Capital" [14], "Corporate Image" [4], and Investment on "Research and Development" [15], with the organizational performance has been analyzed in the different industrial and environmental context.

The accumulation of human resources offers a competitive benefit to improve financial performance. The best human resource is the foundation of a competitive edge and improves economic performance. Correspondingly, human resources have positively impacted the corporate profits and market value of Taiwan companies [15]. Similarly, in a study of Malaysian corporations, a positive linkage was observed between return on assets and human capital [16]. It also explicitly stated that the corporate human capital represents expenditure on employees in accounting terms [17]. The underlying principle is that the expenditure incurred on the workforce should not be treated as costs, but rather it is an asset investment since skilled workers are the prime pillars and value creators of the modern economy. Hence, in this study, Labour and related Expenses/Total Assets ratio [18] is employed to compute the human capital. Labour and related expenses include wages \& salary, provident funds, bonuses, gratuities, and employees' training \& development expenses. In this regard, the following hypotheses are framed:

H1A: The linkage between human capital and return on equity is statistically positive and significant.

H1B: The linkage between human capital and return on assets is statistically positive and significant

Likewise, an effectual corporate image is an imperative determinant of corporate success. Significant intangible resource corporate reputation has the potential to develop a corporate value that is difficult to imitate and replicate for the competitors. Contribution towards community wellness initiatives facilitates corporations to improve their reputation and brand equity [19]. The social responsiveness may have an impact on its stakeholders' judgment and foundation of corporate reputation determinants such as innovation, retention of talented workforce, corporate competence, product and service quality, and especially the financial strength [20]. To analysis the corporate reputation, the price-earnings ratio is employed as an analytical mechanism to appraise the investment risks and growth of earnings. Likewise, it is revealed that the price-earnings ratio is a significant proxy to measure the corporate image [21]. Similarly, the researcher also used the price-earnings ratio to measure the corporate image [22]. Hence, in this study, the price-earnings ratio is used as a proxy of corporate 
reputation. So, in this regard, the following hypotheses are framed:

H2A: The linkage between corporate reputation and return on equity is statistically positive and significant.

H2B: The linkage between corporate reputation and return on assets is statistically positive and significant.

Furthermore, the R\&D of the company is a source of competitive edge on the rivals to imitate the technology and product design. Investment in $R \& D$ is positively linked with corporate performance and innovativeness has a positive impact on corporate performance ROA [23]. Similarly, it is found that $R \& D$ intensity is positively linked with economic performance ROA and ROE [24]. So, keeping in view the deliberations of the above literature, the ratio of $R \& D$ expenditure to sales revenue is taken as an R\&D investments proxy. Therefore, in this regard, the following hypotheses are proposed:

H3A: The linkage between R\&D expenditure and return on equity is statistically positive and significant.

H3B: The linkage between R\&D expenditure and return on assets is statistically positive and significant.

\subsection{Objective of the Study}

The study of relevant literature has provided evidence that the function and relevance of intangible resources have not been thoroughly examined. Furthermore, the role of intangible resources in sustaining competitive advantages has not been fully examined, and there is no evidence that their presence has an impact on corporate performance. Furthermore, in order to acquire valid results, these crucial aspects that were ignored and neglected in previous studies must be empirically studied. As a result of the literature research, the primary goal of the study is to analyze the impact of intangible resources on corporate financial performance.

\section{Database and Research Methodology}

\subsection{Data Sources and Sample}

To investigate the impact of intangible resources on corporate profitability, a thorough assessment of the literature is conducted to identify intangible resources. The sample is selected from the top 200 companies listed on the Bombay Stock Exchange in the manufacturing and consumer products industries. Based on the research and development and corporate reputation variables, only 81 firms have been selected as a final sample from the 200 companies. Companies that did not provide data for the research and development spending and corporate reputation variables were removed from the sample. For the present study, the data have been collected for three years from 2014 to 2016 . The companies that are drawn at the sample for the present study are relevant and they are manufacturing and consumer goods industries. These industries are selected from the diverse sectors of the economy; the manufacturing and consumer goods industry has the maximum impact on the community and environment [25]. The data regarding intangible resources (R\&D, human capital, and corporate reputation), corporate financial performance, and control variables have been taken from the PROWESS database.

\subsection{Research Model and Theoretical Rationale}

Intangible resources are supposed as the foundation of sustainable competitive benefits, as these are indispensable for exploiting projections from rivals [26]. The resource-based theory advocates that to gain sustainable competitive advantages, the company must be capable to administer its resources in such a manner that rival companies will find it difficult to replicate and imitate their qualities [27]. The financial statements are not explaining the real corporate value that underlines the fact that the basis of economic growth is physical as well as intangible, and these resources play a significant role in the creation of companies' sustainable competitive benefits [28]. Only a few types of research have explored how corporate core resources, independently or together, improve corporate economic performance and joint impact of different intangibles resources on corporate profitability [29].

Therefore, keeping in view the earlier literature review and major objective of the study, a suitable conceptual research framework is developed to investigate the impact of intangible resources on corporate financial performance in light of the control variables. Consequently, the present study has employed human capital, corporate reputation, and $R \& D$ as intangible resources to investigate their impact on corporate financial performance.

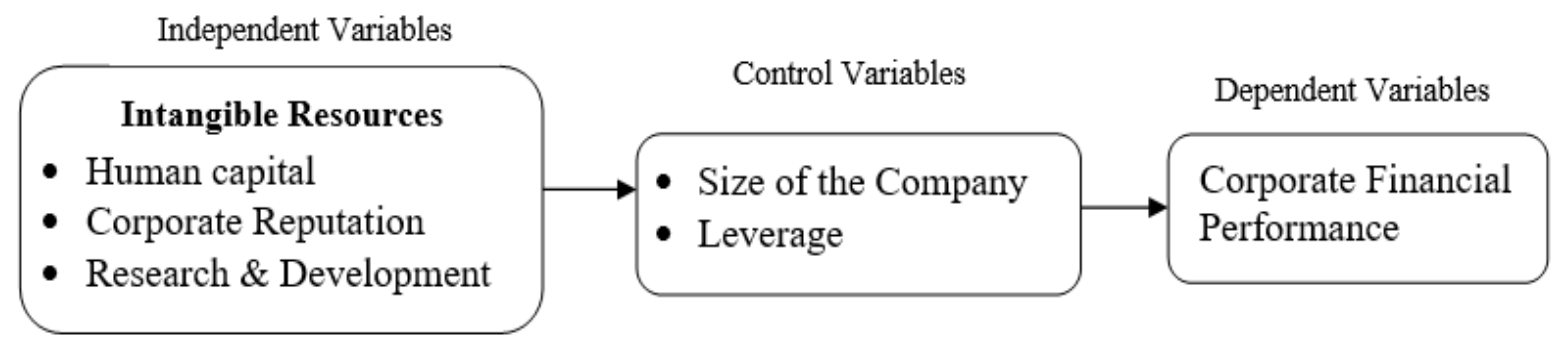

Figure 1. Research Model of Corporate Competitive Advantage 
As Figure 1 indicates, the corporate competitive advantages and core capability are based on intangible resources (Human capital, corporate reputation, and $R \& D$ ) that have an impact on corporate economic performance. The research model of sustainable competitive advantage reflects the processes that associate the vital role of intangible resources with eventual corporate success.

\subsection{Model Specification}

\subsubsection{Dependent and Independent Variables:}

Corporate financial performance is the sole dependent variable, and it has been measured through the two financial performance determinants return on equity (ROE) and return on assets (ROA). A review of earlier literature reveals that ROE and ROA are employed as dependent variables to measure economic performance [30]. The current study has also utilized these two financial performance determinants ROE and ROA following the research works of [31]. Profitability determinant ROA is comprehensively employed, and it has yielded more reliable results as compared to other measures. Likewise, return on equity is also a crucial determinant of profitability, which reflects the management efficiency in yielding higher earnings for investors [32]. However, in the present study; human capital, corporate image, and $R \& D$ are employed as independent variables to determine the relationship.

As determinants of financial performance, ROA and ROE are the dependent variables. The independent variables that influence corporate financial performance are human capital (HUC), corporate reputation (CR), and research and development (R\&D). In addition to this, the control variables are company size (SIZE) and leverage (LEV).

\subsubsection{Analysis and Discussion}

The mean, coefficient of variance, standard deviation as well as correlations are computed and analyzed for descriptive statistics. To investigate the association in light of the intangible resources and control variables, the panel data regression is applied. Furthermore, the regression assumptions validity and specification tests are also analyzed.

In reviewing the literature, it is observed that several other variables have influenced such an association. Accordingly, it is pertinent to control such variables whilst analyzing relationships. However, in this study, the leverage of the company and the company size are considered significant control variables.

So, the logarithm of company total assets is employed as a proxy of company size, corresponding to the study [33]. While, in the case of company leverage, the debt-equity ratio is used as a control variable [34].

\subsubsection{Econometric Specification:}

To explore the impact of corporate intangible resources such as R\&D, human capital, and corporate reputation on the company economic performance in the presence of control variables, the following regression equations are framed to test empirical estimates:

$$
\begin{aligned}
& \mathrm{ROE}_{\text {it }}=\alpha_{0}+\beta_{1} \mathrm{HUC}_{\mathrm{it}}+\beta_{2} \mathrm{REP}_{\mathrm{it}}+\beta_{3} \mathrm{R} \& \mathrm{D}_{\mathrm{it}}+\beta_{4} \mathrm{SIZ} \\
& \mathrm{E}_{\mathrm{it}}+\beta_{5} \mathrm{LEV}_{\mathrm{it}}+\mathrm{e}_{\mathrm{it}}(1) \\
& \mathrm{ROA}_{\text {it }}=\alpha_{0}+\beta_{1} \mathrm{HUC}_{\mathrm{it}}+\beta_{2} \mathrm{REP}_{\mathrm{it}}+\beta_{3} \mathrm{R} \& \mathrm{D}_{\mathrm{it}}+\beta_{4} \mathrm{SIZ} \\
& \mathrm{E}_{\mathrm{it}}+\beta_{5} \mathrm{LEV}_{\mathrm{it}}+\mathrm{e}_{\mathrm{it}}
\end{aligned}
$$

As determinants of financial performance, ROA and ROE are the dependent variables. The independent variables that influence corporate financial performance are human capital (HUC), corporate reputation (CR), and research \& development (R\&D). In addition to this, the control variables are company size (SIZE) and leverage (LEV).

Table 1. Descriptive Statistics

$(\mathrm{N}=243) *$ Correlation is significant at the 0.05 level (2-tailed).

\begin{tabular}{|c|c|c|c|c|c|c|c|c|c|c|}
\hline & Mean & SD & CV & ROA & ROE & LEV & SIZE & HUC & CR & R\&D \\
\hline ROA & 11.81 & 7.97 & 67.52 & 1 & -- & $-0.481^{*}$ & $0.246^{*}$ & $0.498^{*}$ & 0.066 & 0.065 \\
\hline ROE & 22.55 & 15.38 & 68.24 & -- & 1 & $-0.334^{*}$ & $0.148^{*}$ & $0.348^{*}$ & 0.124 & 0.035 \\
\hline LEV & 0.29 & 0.44 & 149.52 & $-0.481^{*}$ & $-0.334^{*}$ & 1 & -0.074 & $-0.300^{*}$ & $-0.163^{*}$ & -0.025 \\
\hline SIZE & 12.53 & 1.02 & 8.13 & $0.246^{*}$ & $0.148^{*}$ & -0.074 & 1 & $0.213^{*}$ & -0.085 & $-0.161^{*}$ \\
\hline HUC & 8.14 & 7.85 & 96.42 & $0.498^{*}$ & $0.348^{*}$ & $-0.300^{*}$ & $0.213^{*}$ & 1 & 0.062 & $0.149^{*}$ \\
\hline CR & 30.71 & 18.46 & 60.10 & 0.066 & 0.124 & $-0.163^{*}$ & -0.085 & 0.062 & 1 & -0.003 \\
\hline R\&D & 1.25 & 2.23 & 179.44 & 0.065 & 0.035 & -0.025 & $-0.161^{*}$ & $0.149^{*}$ & -0.003 & 1 \\
\hline
\end{tabular}




\section{Analysis and Discussion}

The mean, coefficient of variance, standard deviation as well as correlations are computed and analyzed for descriptive statistics. To investigate the association in light of the intangible resources and control variables, the panel data regression is applied. Furthermore, the regression assumptions validity and specification tests are also analyzed.

\subsection{Descriptive Statistics}

Under descriptive statistics (Table 1), the mean, dispersion and correlation among all the variables are analyzed. The descriptive results reflect that the mean of dependent variables ROA and ROE are around 11.81 and 22.55 percent respectively for the whole sample. In regard to the control variables, the mean leverage and company size are is 0.29 and 12.53 percent respectively. Similarly, in the case of intangible resources, the mean human capital, corporate reputation and R\&D are around 8.14, 30.71 and 1.25 percent of the sample. The highest coefficient of variation of 179.44 of $R \& D$ variable reflects that there is a huge difference among the companies regarding R\&D expenditure. In the case of dependent variables, ROA and ROE have depicted the variation of 67.52 and 68.24 percent respectively. During the period of study, it is observed that the mean leverage of 0.29 times reflects that those total liabilities represent an insignificant component of the capital structure.

The Pearson correlations reflect that the highest correlation coefficient is between ROA and human capital variables is 0.498 . Similarly, the correlation between the dependent variable, ROE, and intangible resources human capital, reputation, and R\&D is $0.348,0.124$, and 0.035 respectively.

Similarly, the correlation between the dependent variable, ROA, and intangible resources human capital, reputation, and $\mathrm{R} \& \mathrm{D}$ is $0.498,0.066$, and 0.065 respectively, but it is lower than the standard of 0.80 indicating the non-existence of multicollinearity problem.

\subsection{Diagnostic Tests}

To validate the regression model various diagnostic checks are used to identify the presence of autocorrelation, stationarity, multicollinearity, homoscedasticity. In the case of regression assumption auto-correlation, it is observed that in the case of independent variables ROA and ROE, the value of the Durbin Watson statistic is 2.34 and 2.23 respectively, indicating no autocorrelation among the variables. Likewise, the Augmented Dickey-Fuller test is used to assess the stationary of data. The correlation coefficients among the variables are lower than the standard and the average VIF score of independent and control variables is 1.09 , representing the absence of multicollinearity. Similarly, the problem of heteroscedasticity is checked and it is found that data is Homoscedastic.

\subsection{Specification Tests for Regression Model}

These tests are employed to select the most appropriate regression technique. A redundant fixed effect test is applied to choose the best model between pooled OLS regression and panel data regression. The statistical values of $\left(\chi^{2}\right.$ value 576.11, $\mathrm{p}$-value $\left.=0.000\right)$ and $\left(\chi^{2}\right.$ value 537.71, p-value $=0.000)$ in case of dependent variables ROA \& ROE respectively signify that the panel data regression is preferred over pooled OLS. Similarly, the Hausman test is applied to choose the best model between the REM and FEM. The statistical values of $\left(\chi^{2}=15.77\right.$, $\mathrm{p}$-value $=0.007)$ and $\left(\chi^{2}=21.85\right.$, $\mathrm{p}$-value $\left.=0.000\right)$ in case of dependent variable ROE and ROA signify the selection of the FEM over the REM.

\subsection{Empirical Results and Discussion}

The specification tests have reflected that the FEM is the most appropriate method among all models for regression analyses and the regression coefficients are statistically significant under the fixed effect model.

Table 2 depicts a significant association between intangible resources and financial performance indicators ROE and ROA. It is depicted from the above statistical results that the intangible resources human capital $\left(\mathrm{p}\right.$-value $\left.=0.007^{*}\right)$ and $\mathrm{R} \& \mathrm{D}\left(\mathrm{p}\right.$-value $\left.=0.030^{*}\right)$ has significantly and positively affected corporate performance indicator ROE.

However, the intangible resource corporate reputation ( $\mathrm{p}$-value $\left.=0.000^{*}\right)$ has a significant but negative effect on the corporate financial performance ROE. It implies that intangible resources influence the corporate profitability.

In the case of control variables, the leverage significantly impacted, but the size has an insignificant impact on corporate financial performance. 
Table 2. Panel Data Regression

\begin{tabular}{|c|c|c|c|c|c|c|}
\hline $\begin{array}{c}\text { Dependent } \\
\text { Variable }\end{array}$ & \multicolumn{3}{|c|}{$\begin{array}{c}\text { Return on Equity } \\
\text { Panel (FEM) } \\
\end{array}$} & \multicolumn{3}{|c|}{$\begin{array}{l}\text { Return on Assets } \\
\text { Panel (FEM) }\end{array}$} \\
\hline $\begin{array}{l}\text { Independent } \\
\text { Variable }\end{array}$ & Coefficient & t-Statistic & Prob. & Coefficient & t-Statistic & Prob. \\
\hline HUC & 1.079 & 2.710 & $0.007 *$ & 0.540 & 2.788 & $0.006^{*}$ \\
\hline $\mathrm{CR}$ & -0.184 & -4.658 & $0.000^{*}$ & -0.100 & -5.230 & $0.000^{*}$ \\
\hline $\mathrm{R} \& \mathrm{D}$ & 2.558 & 2.189 & $0.030^{*}$ & 2.287 & 4.017 & $0.000^{*}$ \\
\hline Leverage & -6.589 & -2.070 & $0.040^{*}$ & -3.877 & -2.500 & $0.013^{*}$ \\
\hline Size & 5.330 & 1.492 & 0.137 & 3.393 & 1.949 & $0.053^{* *}$ \\
\hline Observations & \multicolumn{3}{|c|}{243} & \multicolumn{3}{|c|}{243} \\
\hline R-squared & \multicolumn{3}{|c|}{0.9243} & \multicolumn{3}{|c|}{0.9331} \\
\hline Adjusted R-squared & \multicolumn{3}{|c|}{0.8834} & \multicolumn{3}{|c|}{0.8969} \\
\hline F-statistic & \multicolumn{3}{|c|}{22.573} & \multicolumn{3}{|c|}{25.790} \\
\hline Prob. (F-statistic) & \multicolumn{3}{|c|}{$0.000^{*}$} & \multicolumn{3}{|c|}{$0.000^{*}$} \\
\hline \multicolumn{7}{|c|}{ Redundant Fixed Effect Test } \\
\hline Chi-Square Statistic & \multicolumn{3}{|c|}{576.118} & \multicolumn{3}{|c|}{537.715} \\
\hline Prob. & \multicolumn{3}{|c|}{0.000} & \multicolumn{3}{|c|}{0.0000} \\
\hline \multicolumn{7}{|c|}{ Hausman Test } \\
\hline Chi-Sq. Statistic & \multicolumn{3}{|c|}{15.777} & \multicolumn{3}{|c|}{21.859} \\
\hline Prob. & \multicolumn{3}{|c|}{0.007} & \multicolumn{3}{|c|}{0.000} \\
\hline
\end{tabular}

* Significant at 5 percent level of significance

** Significant at 10 percent level of significance

Furthermore, the adjusted R-square ( 88.34 percent) and F-statistics $(p=0.0000)$ represent the best fit of the fixed-effects model. Similarly, the table further depicts that in the case of corporate financial performance determinant ROA, the intangible resources human capital $\left(\mathrm{p}\right.$-value $\left.=0.006^{*}\right)$ and $\mathrm{R} \& \mathrm{D}\left(\mathrm{p}\right.$-value $\left.=0.000^{*}\right)$ have a significant and positive impact. However, the intangible resource corporate reputation $\left(\mathrm{p}\right.$-value $\left.=0.000^{*}\right)$ has a significant but negative impact on corporate profitability. However, the regression coefficients of size and leverage are significant at the given level of significance, revealing their influence on corporate financial performance. Furthermore, the adjusted R-square (89.69 percent) and F-statistics $(p=0.0000)$ represent the best fit of the Fixed effects model.

The statistical results further reflect a positive \& significant linkage between intangible resource human capital and ROE with a regression coefficient of 0.9836 (p-value $=0.013)$. These results are at par with the earlier research works which states that the human resources may facilitate as a competitive edge to the corporations over their rivals and improve profitability. The study observed that human capital positively influences corporate profitability [35]. Likewise, human capital affects the company's profitability positively [36]. Similarly, various researchers [16], [37], [38] revealed that human capital has positive and significant impacts on the corporate economic performance ROE.

In addition to the above results, the association between corporate reputation and ROE is significant but negative with a regression coefficient of -0.1940 (p-value $=0.000$ ). The findings are at par with the findings of [39] which states that company image could not enhance the economic performance. Similarly, the corporate reputation influenced negatively the corporate [40]. In a study, it is found that the association between economic performance (ROE) and the corporate image of the companies is weak [41]. Various researchers like [42], [43] also confirmed a negative linkage between corporate performance indicator ROE and corporate reputation.

Furthermore, the linkage between $\mathrm{R} \& \mathrm{D}$ and $\mathrm{ROE}$ is significant and positive with a regression coefficient of 2.2481 ( $p$-value $=0.050$ ). The present findings are concurrent with the earlier studies that reflected a positive linkage between R\&D and company profits [44], [45]. Further, a considerable impact of $R \& D$ investment on firm financial performance ROE was observed [46]. Similarly, [47] framed a hypothesis to associate the R\&D budget with ROE found improvement in ROE. Similarly, a positive association between $\mathrm{ROE}$ and $\mathrm{R} \& \mathrm{D}$ activities of the manufacturing industry has been observed [48]. On the same pattern in an empirical study, it has been observed that R\&D investment has a positive and significant impact on return on equity [49].

In the case of the second corporate financial performance indicator ROA, the table reflects a significant and positive linkage between intangible resource human capital, and financial performance $(\mathrm{t}$-value $=2.788$ and 
p-value $=0.006$ ). The results are on a par with the study of Malaysian listed companies, that return on asset is positively associated with human capital [16]. Similarly, the linkage between firm performance and human capital confirmed a statistically significant linkage [50]. The results of the current study are also in line with the studies of [36], [51], which states that human resources are the foundation of competitive edge and have a positive impact on return on assets.

Concerning the intangible resource corporate reputation, the present study finds a negative and significant association with ROA (t-value $=-5.230$ and $\mathrm{p}$-value $=0.000$ ). The findings are at par with [52], which states that association between corporate reputation and return on assets is of a weak degree. Similarly, in another opinion, corporate reputation is a crucial strategic resource that must be recognized and corroborated a negative association between ROA and company reputation on Japanese companies [42]. Moreover, [53], [41] empirically investigated the effect of corporate reputation on ROA and found no significant influence.

Furthermore, in the case of the intangible resource $\mathrm{R} \& \mathrm{D}$, there is a significant and positive linkage with ROA ( $\mathrm{t}$-value $=4.017$ and $\mathrm{p}$-value $=0.000$ ). Various researches in the finance and accounting area have examined a positive association between R\&D and firm profitability [45]. The introduction of innovative and quality products has influenced the financial performance of corporate sectors like electronics, pharmaceuticals, automobiles, and information technology [54]. The present findings are consistent with earlier researcher works of [44], [46], who observed that R\&D is significantly and positively linked with ROA. Consequently, the discussion of current findings considering the earlier literature observed that the corporate financial performance is significantly influenced by intangible assets human capital, corporate reputation, and $R \& D$ investments.

\subsection{Discussion of Hypotheses Testing.}

The six alternative hypotheses are framed to predict the association between intangible resources and corporate financial performance. In the following table, p-values reflect that the alternative hypotheses are accepted at a given level of significance and fully supported by the empirical literature.

The table reflects that the p-values signify the acceptance of alternative hypotheses, meaning that intangible resources human capital and R\&D have a positive and significant influence on the financial performance. However, the corporate reputation has negative influence on financial performance; however, the findings are statistically significant.

Table 3. Summary of the Tested Hypotheses

\begin{tabular}{|c|c|c|c|c|}
\hline \multicolumn{2}{|c|}{ Hypotheses } & Description & p-values & Result \\
\hline \multirow{2}{*}{$\mathrm{H}_{1}$} & $\mathrm{H}_{1 \mathrm{~A}}$ & $\begin{array}{c}\text { The linkage between human capital and return on equity is } \\
\text { statistically positive and significant. }\end{array}$ & 0.007 & Supported \\
\cline { 2 - 6 } & $\mathrm{H}_{1 \mathrm{~B}}$ & $\begin{array}{c}\text { The linkage between human capital and return on assets is } \\
\text { statistically positive and significant }\end{array}$ & 0.006 & Supported \\
\hline \multirow{2}{*}{$\mathrm{H}_{2}$} & $\mathrm{H}_{2 \mathrm{~A}}$ & $\begin{array}{c}\text { The linkage between corporate reputation and return on equity } \\
\text { is statistically positive and significant. }\end{array}$ & 0.000 & Supported \\
\cline { 2 - 6 } & $\mathrm{H}_{2 \mathrm{~B}}$ & $\begin{array}{c}\text { The linkage between corporate reputation and return on assets } \\
\text { is statistically positive and significant. }\end{array}$ & 0.000 & Supported \\
\hline \multirow{2}{*}{$\mathrm{H}_{3}$} & $\mathrm{H}_{3 \mathrm{~A}}$ & $\begin{array}{c}\text { The linkage between R\&D expenditure and return on equity is } \\
\text { statistically positive and significant. }\end{array}$ & 0.030 & Supported \\
\cline { 2 - 6 } & $\mathrm{H}_{3 \mathrm{~B}}$ & $\begin{array}{c}\text { The linkage between R\&D expenditure and return on assets is } \\
\text { statistically positive and significant. }\end{array}$ & 0.000 & Supported \\
\hline
\end{tabular}




\section{Managerial Implications}

The above-mentioned findings are based on data collected and evaluated from 81 firms across several industries, and they have a wide range of consequences for managers, academics, and practitioners. It is evident from the results that humans are an imperative resource that facilitates a value creator and competitive edge for corporations over their rivals. In the knowledge-driven economy, managers and corporations must value their human assets as an indispensable resource and improve them by investing in various development programs [55]. It is also acknowledged that investment in $R \& D$ and innovation activities enables the corporations to gain a rich market share and enhanced sale revenues. Likewise, employees are the corporate elemental resources that improve technological development and corporate productivity which sequentially increase corporate profitability. Hence, results of the study will enhance the corporation's focus on R\&D investments, technological upgradations, provision of quality products and services to the community, and the optimal utilization of scarce corporate resources [56]. Results of the study highlights the emergence of corporate reputation as a significant mechanism to facilitate the stakeholders to draw a line of differentiation among competent corporations and incompetent corporations by reviewing their earlier performance [57].

\section{Conclusions}

The organizational investment trends are rapidly changing in the current business environment where the firm's physical resources do not assure the relevant increase in the organizational wealth and competitive advantages. Thus, determining the organization's intangible recourses and, their influence on the organizational performance could provide a more accurate picture for managerial decisions. Numerous researchers and academicians discussed in the present study highlighted the importance of intangible resources and inferred a significant influence on the organization's performance. Based upon similar assumptions, the results of the present study also indicated the significant role of human capital, corporate image, and R\&D on organizational performance.

The empirical literature reflected a mixed impact of intangible resources $\mathrm{R} \& \mathrm{D}$, human capital, and corporate reputation on company financial performance. The in-depth analysis of the resource-based view has revealed that corporations can boost their internal capabilities and potential, principally through the effective management of intangible resources [58], and intangible resources can be the key factor in the foundation of corporate competitive advantage. Taking the reference of the above-stated studies and results of the study, profit-seeking corporations can avail the opportunities of making the investment in human capital [59], R\&D and innovation [60], and corporate reputation [61]. Modern corporations are more eager to improve their profitability through investing in research and innovation activities. The R\&D expenditures are extensively recognized as an intangible investment that has a positive influence on corporate profitability and investors' returns [62]. Similarly, in a knowledge-based economy, human capital also facilitates a momentous role in the sustainability of company profits [63]. Enriched human resources provide competitive advantages that serve as the vital mechanism for enhancing the corporate future profitability economic stability. Moreover, the asset human resources are the foundation of innovative ideas that provide a competitive edge for the companies to improve their corporate reputation [64]. On the same pattern, the corporate reputation is also a crucial foundation of intangible resources that facilitates a competitive edge over the competitors, since it is intricate to imitate and replicate. Thus, building and sustaining a positive corporate image is a fundamental basis for corporations to maintain and survive with enhanced profitability.

\section{REFERENCES}

[1] Hitt, M. A., Ireland, R. D., Hoskisson, R. E, "Strategic Management: Competitiveness and Globalization", 2009 Cengage Southwestern Publishing Co., OH, USA. https://books.google.com.sa/books?hl=en\&lr=\&id=wUPA AgAAQBAJ\&oi=fnd\&pg=PR1\&dq=related:99ygN3FvPsk $\mathrm{J}$ :scholar.google.com/\&ots=SNd8MCT3P3\&sig=N5A0oec vWTOOPlnUDoDDNBbXx4E\&redir_esc $=\mathrm{y} \# \mathrm{v}=$ onepage $\&$ $\mathrm{q} \& \mathrm{f}=$ false

[2] Petrick, J. A., Scherer, R. F., Brodzinski, J. D., Quinn, J. F., Ainina, M. F, "Global leadership skills and reputational capital: Intangible resources for sustainable competitive advantage". Academy of Management Perspectives, 13(1), 58-69, 1999. https://doi.org/10.5465/ame.1999.1567322

[3] Kak, A., Sushil, H, "Sustainable competitive advantage with core competence: a review". Global Journal of flexible systems management, 3(4), pp 23-38, 2002. https://www.researchgate.net/publication/273395807_Sust ainable_Competitive_Advantage_with_Core_Competence _A_Review/link/57ac003a08ae4 $\overline{2}$ ba52af354ē/download

[4] Inmyxai, S., Takahashi, Y, "The effect of firm resources on business performance of male-and female-headed firms in the case of Lao micro-, small-, and medium-sized enterprises (MSMEs)", International Journal of Business and Information, 5(1) 2010.DOI:10.6702/IJBI.2010.5.1.4

[5] Ahangar, R. G, "The relationship between intellectual capital and financial performance: An empirical investigation in an Iranian company", African journal of business management, 5(1), pp 88-95 2011. https://doi.org/10.5897/AJBM10.712

[6] Bornemann, M, "Potential of value systems in Austria 
according to the VAIC", International Journal of Technology Management, Vol.18 No.5/6/7/8, pp.463-475, 1999. https://dx.doi.org/10.1504/IJTM.1999.002781

[7] Brennan, N., Connell, B, "Intellectual capital: current issues and policy implications", Journal of Intellectual capital, 1 (3), pp 206-240, 2000.https://doi.org/10.1108/1469193001 0350792

[8] Ray, G., Barney, J.B., Muhanna, W.A, "Capabilities, business processes and competitive advantage: choosing the dependent variable in empirical test of resource-based view" Strategic Management Journal, Vol. 25, pp. 23-37, 2004. https://doi.org/10.1002/smj.366

[9] Runyan, R. C., Huddleston, P., Swinney, J, "Entrepreneurial orientation and social capital as small firm strategies: A study of gender differences from a resource-based view", The International Entrepreneurship and Management Journal, 2(4), pp 455-477, 2006. https://doi.org/10.1007/s11365-006-0010-3

[10] Apintalisayon, "Tangible versus intangible assets", 2008. available at: http://apintalisayon.

[11] Mathews, J. A, "Resource and activities are two sides of the same coin: duality of the activities and resource-based views of strategic management", In Conference on Strategic Management, Copenhagen, 2006. https://www.re searchgate.net/profile/John-Mathews-8/publication/228458 325

[12] Nelson, R. R., Winter, S. G, "Evolutionary theorizing in economics. Journal of economic perspectives, 16(2), pp 23-46, 2002. DOI: 10.1257/0895330027247

[13] Firer, S., Williams, S. M, "Intellectual capital and traditional measures of corporate performance", Journal of intellectual capital. Vol. 4 Issue: 3, pp.348-360, 2003. https://doi.org/10.1108/14691930310487806

[14] Kraja Y. B., Shkoder L. G, "The impact of tangible and intangible assets on the SMEs' success: the Albanian case", In: Ateljevic J, Budak J, editors. Entrepreneurship in post-communist countries. Springer, 2018. http://dx.doi.or g/10.1007/978-3-319-75907-4_9

[15] Chun H., Nadiri I. M, "Intangible investment and changing sources of growth in Korea", The Japanese economic review. J Japanese Econ Assoc. 67(1), pp 50-76, 2016. doi: $10.1111 /$ jere. 12079

[16] Chen, C. J., Liu, T. C., Chu, M. A., Hsiao, Y. C, "Intellectual capital and new product development", Journal of Engineering and Technology Management, 33, pp 154-173, 2014. https://doi.org/10.1016/j.jengtecman.20 14.06.003

[17] Ting, I. W. K., Lean, H. H, "Intellectual capital performance of financial institutions in Malaysia", Journal of Intellectual Capital, 10(4), pp 588-599, 2009. http://dx.doi.org/10.1108/14691930910996661

[18] Pulic, A, "The principles of intellectual capital efficiency-A brief description", Croatian Intellectual Capital Center, Zagreb, 76, pp 1-24, 2008. https://asset-pdf.scinapse.io/pro $\mathrm{d} / 2371185822 / 2371185822 . p d f$

[19] Scafarto, V., Ricci, F., Scafarto, F, "Intellectual capital and firm performance in the global agribusiness industry",
Journal of Intellectual Capital, 17(3), pp 530-552, 2016. https://doi.org/10.1108/JIC-11-2015-0096

[20] Rowley, T., Berman, S, “A brand new brand of corporate social performance", Business \& society, 39(4), pp 397-418, 2000. https://doi.org/10.1177\%2F000765030003900404

[21] De Castro, G. M., López, J. E. N., Sáez, P. L, "Business and social reputation: Exploring the concept and main dimensions of corporate reputation", Journal of Business Ethics, 63(4), pp 361-370, 2006. http://dx.doi.org/10.1007/ s10551-005-3244-z

[22] Little, P. L, "Determinants of Price-Earnings Ratios in the Oil and Gas Industry", Allied Academies International Conference. Academy of Accounting and Financial Studies. Proceedings (Vol. 2, No. 2, pp. 136). Jordan Whitney Enterprises, Inc. 1997.

[23] Caruana, A. (1997). Corporate reputation: concept and measurement. Journal of Product and Brand Management, 6(2), 109-118. Catuogno, S., Allini, A., and Pulcinelli, I. (2013). Accounting comparability and firm's reputation. An exploration of the Italian experience for joint controlled entities. Proceedings on GV--Global Virtual Conference; No. 1. Available from: http://www.gv-conference.com/arc hive/?vid=1\&aid=2\&kid=30101-92

[24] Naik, P. K., Narayanan, K., Padhi, P, "R\&D intensity and market valuation of firm: A study of $R \& D$ incurring manufacturing firms in India", Journal of Studies in Dynamics and Change, 1(7), pp 295-308, 2014. https://mpra.ub.uni-muenchen.de/id/eprint/37299

[25] Lucius, H. W., Habte-Giorgis, B., Lee, J, “Empirical study of the strategic impact of major marketing factors on firms accounting performance in the pharmaceutical industry", In Building Bridges in a Global Economy (p. 13). Higher School of Commercial Management and Marketing, ESIC, 2008.

https://dialnet.unirioja.es/servlet/articulo? codigo=2710856

[26] Burritt, R. L., Schaltegger, S., Bennett, M., Pohjola, T., Csutora, M, "Environmental management accounting and supply chain management", (Vol. 27), 2011. Springer Science \& Business Media.

[27] Nason, R. S., Wiklund, J, “An assessment of resource-based theorizing on firm growth and suggestions for the future", Journal of Management, 44(1), pp 32-60, (2018). https://doi.org/10.1177\%2F0149206315610635

[28] Barney, J., Hesterly, W. S, "Strategic Management and Corporate Competitive Advantage: Concepts", 2012. Prentice Hall, New Jersey, USA https://www.worldcat.org/ title/strategic-management-and-competitive-advantage-con cepts-and-cases/oclc/297146325

[29] Kaplan, R.S. Norton, D. P, "Strategy Maps: Converting Intangible Assets into Tangible Outcomes", 2004, Harvard Business School Press, Boston, MA. https://store.hbr.org/p roduct/strategy-maps-converting-intangible-assets-into-tan gible-outcomes/1342

[30] Carmeli, A., Tishler, A, "The relationships between intangible organizational elements and organizational performance". Strategic Management Journal, 25(13), pp 1257-1278, 2004. https://doi.org/10.1002/smj.428

[31] Saleh, M., Zulkifli, N., Muhamad, R, "Looking for evidence of the relationship between corporate social responsibility 
and corporate financial performance in an emerging market", Asia-Pacific Journal of Business Administration, 3(2), pp 165-190, 2011.https://doi.org/10.1108/175743211 11169849

[32] Kang, K.H., Lee, S. Huh, C, "Impacts of positive and negative corporate social responsibility activities on company performance in the hospitality industry", International Journal of Hospitality Management 29(1), pp 72-82, 2010. https://doi.org/10.1016/j.ijhm.2009.05.006

[33] Bagchi, B., Khamrui, B, "Financial performance of FMCG companies in India: A comparative study between Britannia Industries and Dabur India", Zenith International Journal of Business Economics and Management Research, 2(3), pp 222-232, 2012. http://zenithresearch.org.in/

[34] Clarkson, M. E, “A stakeholder framework for analyzing and evaluating corporate social performance", Academy of Management Review, 20(1), pp 92-117, 1995. https://doi.org/10.5465/amr.1995.9503271994

[35] Andrikopoulos, A., Kriklani, N, "Environmental disclosure and financial characteristics of the firm: The case of Denmark", Corporate Social Responsibility and Environmental Management, 20(1), pp 55-64, 2013. https://doi.org/10.1002/csr.1281

[36] Perera, A., Thrikawala, S, "Impact of human capital investment on firm financial performances: An empirical study of companies in Sri Lanka", International Proceedings of Economics Development and Research, 54(3), pp 11-16, 2012. doi: 10.7763/ipedr. 2012. v54. 3

[37] Amin, S, "Does the entrepreneurial human capital is important for organizational performance?", Business and Economics Journal, 9(2), pp 1-5, 2018. Doi:10.4172/2151-6219.1000350

[38] Maditinos, D., Chatzoudes, D., Tsairidis, C., Theriou, G, "The impact of intellectual capital on firms' market value and financial performance", Journal of Intellectual Capital, 12(1), pp 132-151, 2011. http://dx.doi.org/10.1108/146919 31111097944

[39] Salman, R. T., Mansor, M., Babatunde, A. D., Tayib, M, "Impact of intellectual capital on return on asset in Nigerian manufacturing companies", Interdisciplinary Journal of Research in Business, 2(4), pp 21-30, 2012. https://www.researchgate.net/publication/329999399

[40] Rose, C., Thomsen, S, "The Impact of Corporate Reputation on Performance: Some Danish Evidence", European Management Journal, 22(2), pp 201-210, 2004. http://www.sciencedirect.com/science? ob=JournalURL\& cdi $=5907 \&$ auth $=y \&$ acct $=C 000024838 \&$ version $=1 \&$ urlVersion $=0$ \& userid $=523703 \& \mathrm{md} 5=5188878 \mathrm{a} 064 \mathrm{~d} 6370$ $\mathrm{c} 5 \mathrm{~b} 8 \mathrm{ec} 0 \mathrm{da} 10 \mathrm{~d} 50 \mathrm{c} 1$

[41] Olmedo-Cifuentes, I., Martínez-León, I, "Human capital and creation of reputation and financial performance", Electronic Journal of Knowledge Management, 13(3), pp 209-218, 2015. https://psycnet.apa.org/record/2015-50449005

[42] Vig, S., Dumicic, K., Klopotan, I, “The impact of reputation on corporate financial performance: Median regression approach", Business Systems Research Journal, 8(2), pp 40-58, 2017. https://doi.org/10.1515/bsrj-2017-0015
[43] Hall, E. H., Lee, J, "Assessing the impact of firm reputation on performance: an international point of view", International Business Research, 7(12), pp 1-13, 2014. doi:10.5539/ibr.v7n12p1

[44] Blajer Golebiewska, A, "Corporate reputation and economic performance: The evidence from Poland. Economics \& Sociology, 7(3), pp 194-207, 2014. http://dx.doi.org/10.14254/2071-789X.2014/7-3/15

[45] Wang, Y., Fan, W, "R\&D reporting methods and firm value: evidence from China", Chinese Management Studies, 8(3), pp 375-396, 2014. http://dx.doi.org/10.1108/CMS-01-2013 $-0019$

[46] Freihat, A. R. F., Kanakriyah, R, "Impact of R\&D expenditure on financial performance: Jordanian evidence", European Journal of Business and Management, 9(32), pp 73-83, 2017.https://www.researchgate.net/profile/Raed-Ka nakriyah/publication/321849135

[47] Ghaffar, A., Khan, W. A, "Impact of research and development on firm performance", International Journal of Accounting and Financial Reporting, 4(1), pp 357-367, (2014). http://dx.doi.org/10.5296/ijafr.v4i1.6087

[48] Rao, J., Yu, Y., Cao, Y, "The effect that R\&D has on company performance: comparative analysis based on listed companies of technique intensive industry in China and Japan", International Journal of Education and Research, 1(4), pp 1-8, 2013. https://www.ijern.com/image s/April-2013/40.pdf

[49] Schimke, A., Brenner, T. "The role of R\&D investments in highly R\&D-based firms", Studies in Economics and Finance, (1), pp 3-45, 2014. http://dx.doi.org/10.1108/SEF $-02-2012-0017$

[50] Ozturk, E., Zeren, F, "The impact of R\&D expenditure on firm performance in manufacturing industry: further evidence from Turkey", International Journal of Economics and Research, 6(2), pp 32-36, 2015. $\mathrm{http} / / /$ ijeronline.com/documents/volumes/2015/Vol\%206\% 20Iss\%2002\%20MA\%202015/ijer\%20v6\%20i3\%20ma\%2 $0(4) . p d f$

[51] Mondal, A., Ghosh, S. K, "Intellectual capital and financial performance of Indian banks", Journal of Intellectual Capital, 13(4), pp 515-530, 2012. https://doi.org/10.1108/1 4691931211276115

[52] Odhon'g, E. A., Omolo, J, "Effect of human capital investment on organizational performance of pharmaceutical companies in Kenya", Global Journal of Human Resource Management, 3(6), pp 1-29, 2015. http://economics.ku.ac.ke/images/Omolo.pdf

[53] Shi, Y, "Reputation, financial performance, and industry competition", The International Journal of Business and Finance Research, 10(2), pp 1-16, 2016. http://www.theibf r2.com/RePEc/ibf/ijbfre/ijbfr-v10n2-2016/IJBFR-V10N22016-1.pdf

[54] Ito, K., Pucik, V, "R\&D spending, domestic competition, and export performance of Japanese manufacturing firms", Strategic Management Journal, 14(1), pp 61-75, 1993. https://www.jstor.org/stable/2486550

[55] Vivero, R. L, “The impact of process innovations on firm's productivity growth: the case of Spain. Applied Economics, 
34(8), pp 1007-1016., 1993. wordpress.com / 2008 /12/14 /d11-tangible-versus-intangible-assets/ (accessed 29 March 2020).

[56] Tayles, M., Pike, R. H., Sofian, S. "Intellectual capital, management accounting practices and corporate performance", Accounting, Auditing \& Accountability Journal, 20(4), pp 522-548, 2007. https://econpapers.repec .org/RePEc:eme:aaajpp:v:20:y:2007:i:4:p:522-548

[57] Mizik, N., Jacobson, R, "Trading off between value creation and value appropriation: The financial implications of shifts in strategic emphasis", Journal of Marketing, 67(1), pp 63-76, 2003.https://doi.org/10.1509\%2Fjmkg.67.1.63.1 8595

[58] Mailath, G. J., Samuelson, L, "Who wants a good reputation?.", The Review of Economic Studies, 68(2), pp 415-441, 2001. https://doi.org/10.1111/1467-937X.00175

[59] Fleisher, G. S, "Strategic and competitive analysis. Methods and techniques for analyzing business competition", 2002. New Jersey: Prentice Hall. https://www.researchgate.net/publication/265224384 Strat egic_and_Competitive_Analysis_Methods_and_Technique s_for_Analyzing_Business_Competition

[60] Wright, M., Hmieleski, K. M., Siegel, D. S., Ensley, M. D, "The role of human capital in technological entrepreneurship", Entrepreneurship Theory and Practice, 31(6), pp 791-806, 2007. https://doi.org/10.1111\%2Fj.154 0-6520.2007.00202.x

[61] Helfat, C. E, "Know - how and asset complementarily and dynamic capability accumulation: the case of R\&D", Strategic Management Journal, 18(5), pp 339-360, 1997. https://citeseerx.ist.psu.edu/viewdoc/download?doi=10.1.1 $.466 .6867 \&$ rep $=$ rep $1 \&$ type $=$ pdf

[62] Roberts, P. W., Dowling, G. R, "Corporate reputation and sustained superior financial performance", Strategic Management Journal, 23(12), pp 1077-1093, 2002. https://doi.org/10.1002/smj.274

[63] Hall, B, "Mergers and R\&D revisited. In Prepared for the Quasi Experimental Methods Symposium, Econometrics Laboratory, US Berkeley, (1999). Available at: https://www.researchgate.net/publication/2353839_Merger s_and_RD_Revisited

[64] Yusuf, I, "The relationship between Human Capital Efficiency and Financial Performance: An Empirical Investigation of Quoted Nigerian Banks", Research Journal of Finance and Accounting, 4(4), pp 1-14, 2013. https://ssrn.com/abstract=2943339

[65] Zhu, W., Chew, I. K., Spangler, W. D, “CEO transformational leadership and organizational outcomes: The mediating role of human-capital-enhancing human resource management", The Leadership Quarterly, 16(1), pp 39-52, 2005. https://doi.org/10.1016/j.leaqua.2004.06.0 01 